\title{
REPTILES AND AMPHIBIANS OF CURAÇAO
}

BY

\author{
Dr. NELLY DE ROOIJ.
}

(With 2 Figures).

The Zoological Museum of Amsterdam received some collections of reptiles from Curaçao made by Dr. J. BoeKe in 1905, by Dr. C. J. van DeR Horst in 1920 and by Mr. G. J. H. MolengraAfF „Engineer” in 1921. I had the opportunity of studying them and will here give an enumeration of all the reptiles known from that island, followed by some data concerning the species in the possession of the Amsterdam Museum.

GECKONIDAE.

Gymnodactylus antillensis Lidth

Gonatodes albogularis D. B.

Gonatodes vittatus (Licht.) ${ }^{1}$ )

Phyllodactylus julieni Cope

Phyllodactylus spatulatus Cope

Thecadactylus rapicaudus Houtt.

IGUANIDAE.

Anolis lineatus Daud.

Iguana tuberculata Laur.

TEIIDAE.

Cnemidophorus murinus Laur.

Cnemidophorus arubensis Lidth

Gymnophthalmus quadrilineatus $\mathrm{L}$.

CHELONIDAE.

Chelonia mydas L.

Caretta caretta (L.)

COLUBRIDAE.

Dromicus antillensis Schleg.

Liophis triscalis (L.)

VIPERIDAE.

Crotalus terrificus Laur.

CYSTIGNATHIDAE.

Paludicola brachyops (Cope)

1) Perhaps a variety of G. albogularis, Cat. Liz. III, p. 481 . 
GECKONIDAE.

Gymnodactylus antillensis Lidth.

Th. W. van Lidth De Jeude, Notes Leyden Mus. IX 1887, p. 129, pl. 2, fig. 1.

Curaçao, 4.1905, 1 spec., B. leg.

” 26.7.1905, 1 spec., B. leg.

” $6.1905,7.1905$, a number of embryos, B. leg.

Caracas Bay, 7.4.1920, 12.4.1920, 26.5.1920, 3 spec., v. d. H. leg.

Brakke Put, 21.5.1920, 1 spec., v. d. H. leg.

Plantage Knip, 27.5.1920, 1 spec., v. d. H. leg.

Known from Aruba and Curaçao only.

Head rather small, depressed; snout pointed, about as long as the diameter of the orbit; ear-opening small. Head granular, the granules on the snout much larger. Rostral large with a median cleft, followed by two smaller shields, which are separated by a small azygos scale; nostril bordered by the rostral, the shield behind the rostral, the first labial and two smaller scales. Six upper and five lower labials, the first lower labial very large; mental very large, followed by a large median chin-shield and some smaller shields on each side. Throat with small granules. Body elongate, covered above with equal round, smooth tubercles, those on the median line somewhat smaller. Ventral scales large, imbricate, smooth, 16-18 across the middle of the belly. No femoral or praeanal pores. Tail round, covered with small, equal, imbricate scales above, large ones beneath, especially those of the median row. Limbs slender; digits long, slightly depressed at the base, which has enlarged transverse plates inferiorly, compressed in the distal part.

Brown above with dark brown transverse bands, bordered behind with yellowish, the two anterior from eye to eye, one over the occiput, the second across the nape, the bands disappearing in the adults. Lower surface yellowish-brown, each scale punctulated with dark brown. Total length $70 \mathrm{~mm}$.

Fig. 1. Gymnodactylus antillensis Lidth. Tubercles of the back; inferior part of digit

Gonatades albogularis (D. B.).

G. A. Boulenger, Cat. Liz. Brit. Mus. I 1885, p. 59 .

Curaçao, $4.1905,2$ spec. $\sigma^{7}$, B. leg.

Otrabanda, 7.1905, 2 spec. ㅇ juv., B. leg.

A number of embryos, B. leg.

Known from Curaçao, Aruba, Surinam, Cuba, Jamaica. The biggest specimen measures $32 \mathrm{~mm}$. from the tip of the snout to the vent.

Phyllodactylus julieni Cope.

E. D. Cope, Proc. Phil. Soc. XXII, nº 118,1885 , p. 180.

Th. W. van Lidth DE Jeude, Notes Leyden Mus. IX, 1887, p. 130, pl. 2, fig. 2, 3 (as P. martini).

Otrabanda, 7.1905, 1 spec., B. leg.

Brakke Put, 21.5.1920, 3 spec., v. d. H. leg.

Known from Aruba and Curaçao only.

Nom. indig.: Toertikie pega-pega.

The single specimen collected by Dr. BoEKE measures $48+60 \mathrm{~mm}$. (tail), the largest from Brakke Put $53+61 \mathrm{~mm}$. The authors mentioned above did not give measurements. 
Head large, depressed; snout rounded, about once and a half the diameter of the orbit; earopening oblique, half the diameter of the orbit. Head covered with round tubercles, those on the snout flat, the others convex. Rostral large with a median cleft, followed by two smaller shields; nostril bordered by the rostral, the shield behind the rostral, the first labial and two smaller scales. Ten to twelve upper and seven to nine lower labials, the last two or three very small, first lower labial large; mental large, pentagonal, followed by two large chin-shields in the middle, the next much smaller. Throat with small scales. Body covered with small granules and about 18 longitudinal

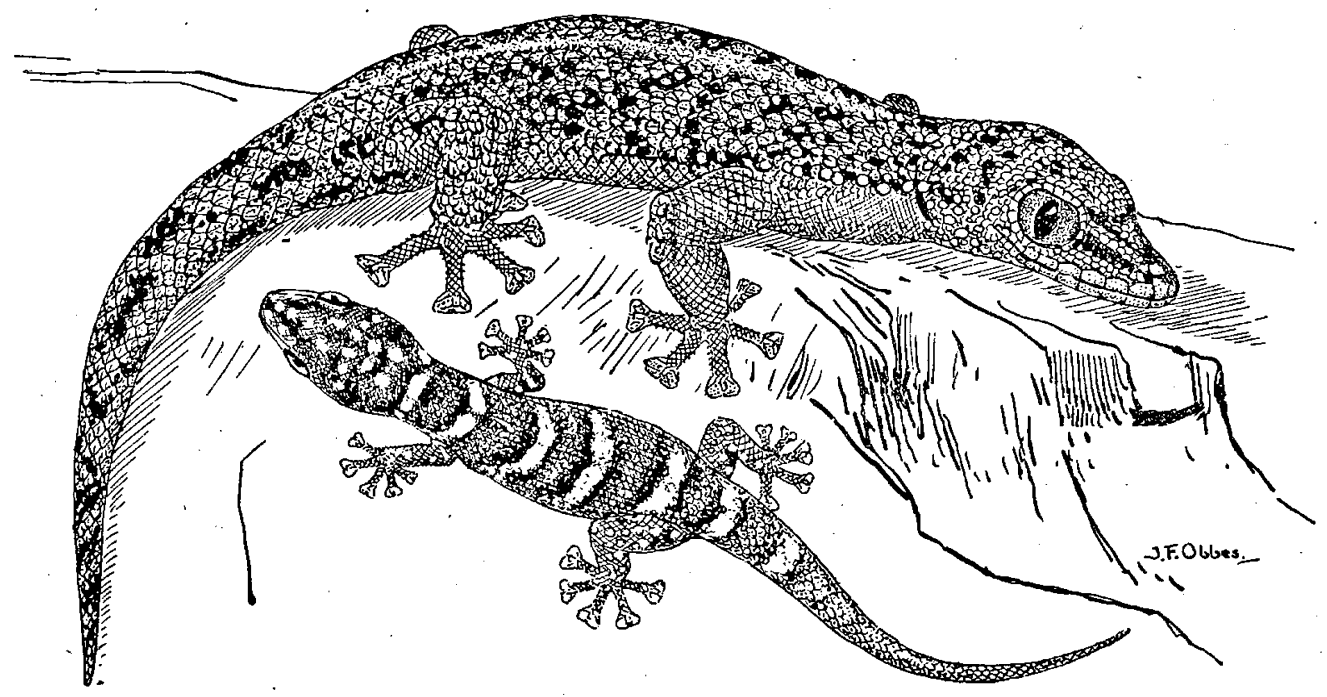

Fig. 2. Phyllodactylus julieni Cope.

rows of large keeled tubercles, median line granular. Ventral scales smooth, cycloid, imbricate, 24 across the middle of the belly. No femoral or preanal pores. Tail round, covered above with small scales and keeled tubercles in annuli, beneath with a median series of broad plates. Limbs slender; digits with a row of scales inferiorly, the distal expansion broad; limbs covered above with granules intermixed with keeled tubercles.

Light brown above with dark brown markings. Young specimens dark brown with four or five whitish black-edged transverse bands between axilla and groin and another band on the nape; head and limbs with small round white spots; a dark band from the nostril to the ear passing through the eye. Lower parts yellowish, punctulated with brown.

Thecadactylus rapicaudus (Houtt.).

G. A. Boulenger, Cat. Liz. Brit. Mus. I 1885, p. 111.

Brakke Put, 15.5.1920, 1 spec., v. d. H. leg.

” $\quad 5.1920,4$ spec., v. d. H. leg.

Rather common in many of the West-Indian islands, Surinam and other places of Central and South America.

Nom. indig.: Pega-pega.

\section{IGUANIDAE.}

Anolis lineatus Daud.

G. A. Boulenger, Cat. Liz. Brit. Mus. II 1885, p. 38.

Albertine near St. Joris Bay, 8.4.1920, 4 spec., v. d. H. leg.

Caracas Bay, 30.4.1920, 22.5.1920, 2 spec., v: d. H. leg.

Jan Tiel, 7.5.1920, 13 spec., v. d. H. leg.

Known from Aruba and Curaçao only, rather common in Curaçao. 
Iguana tuberculata Laur.

G. A. Boulenger, Cat. Liz. Brit. Mus. II 1885, p. 189.

Curaçao, 1905, 3 spec., B. leg.

Caracas Bay, 8.4.1920, 8.5.1920, 13.5.1920, 3 spec. v. d. H. leg.

TEIIDAE.

Cnemidophorus murinus (Laur.).

G. A. Boulenger, Cat. Liz. Brit. Mus. II 1885, p. 361.

Curaçao, 4.1905, 1 spec., B. leg.

Caracas Bay, 18.4.1920, 26.4.1920, 11.5.1920, 20.5.1920, 23.5.1920, 10 spec., v. d. H. leg.

Jan Tiel, 7.5.1920, 3 spec. (2 juv.), v. d. H. leg.

Known from Guianas, Trinidad, Curaçao, Aruba and Bonaire.

Nom. indig.: Toertikie ragadiesjie; blausana.

The largest specimen measures $147 \mathrm{~mm}$. from the tip of the snout to the vent.

Cnemidophorus arubensis Lidth.

Th. W. van Lidth De Jeude, Notes Leyden Mus. IX 1887, p. 132.

Curaçao, 15.7.1905, 16.7.1905, 2 spec. ơ, ㅇ, B. leg.

Known from Aruba only to which place Curaçao now may be added.

Nom. indig.: Blausana.

Shows much resemblance to Cnemidophorus murinus, but may be distinguished at first sight by the number of the rows of ventrals, which is 8 and not 10 or 12 .

The male is olive-green with many bluish round spots on the sides and the hind limbs. It has 30 femoral pores and its praeanals are arranged in two rows: 0

The female is light olive, no blue spots. It has 14 femoral pores and its praeanals are arranged in two rows: 00

Dr. BOEKE captured two male specimens on Aruba too, one with 31 the other with 30 femoral pores. Total length of largest specimen $367 \mathrm{~mm}$. (tail $265 \mathrm{~mm}$.).

Gymnophthalmus quadrilineatus (L.).

G. A. Boulenger, Cat. Liz. Brit. Mus. II 1885, p. 427.

Klip, 10.7.1905, 18.7.1905, 8. 1905, 4 spec. (1 б", 3 ९), B. leg.

Curaçao, 26.7,1905, 6 spec. (2 o', 4 o ), B. leg.

Caracas Bay, 7.5.1920, 1 spec. ㅇ, v. d. H. leg.

Santa Catharina, 12.5.1920, $1 \mathrm{spec}$. , v. d.' H. leg.

Brakke Put, 15.5.1920, 9 spec. (5 \&, $\left.4 \sigma^{7}\right)$, v. d. H. leg.

Known from Brazil (Cat. Liz.) and Curaçao. Not rare in the island.

Nom. indig.: Colebra mispel and colebra meesteri.

\section{COLUBRIDAE.}

Liophis triscalis (L.).

G. A. Boulenger, Cat. Snakes Brit. Mus. II 1894, p. 129.

Hato, 1905, 1 spec., B. leg.

Willemstad, 3.5.1920, 1 spec., v. d. H. leg.

Brakke Put, 15.5.1920, 1 spec. juv., v. d. H. leg.

Caracas Bay, 28.5.1920, 1 spec., v. d. H. leg.

Mount Pleasant, 15.12.1921, 1 spec., M. leg.

This species is one of the three representatives of the snakes in Curaçao, and not rare. Its 
occurrence in Venezuela, Surinam and Paraguay is not certain. The specimen from Caracas Bay has a length of $852 \mathrm{~mm}$. All five specimens have very distinct dark lines, three on the back, two on tile tail.

VIPERIDAE.

Crotalus terrificus (Laur.).

G. A. Boulenger, Cat. Snakes Brit. Mus. III 1896, p. 573.

Curaçao, 1885, 1 spec., v. d. Poll don.

A specimen of rattle-snake, doubtless belonging to this species has been for a long time already in the collection of the Amsterdam museum. It does not show very distinct markings; the snout is covered with large shields: a pair of internasals and a pair of praefrontals, both in contact on the median line; another pair of large shields between the supraoculars, followed by two smaller ones which are separated by small scales. Supraoculars without a horn-like process. Length of head and body $835 \mathrm{~mm}$.; tail $106 \mathrm{~mm}$.

New for Curaçao; known from Central and South America. In 1887 Dr. VAN LIDTH DE JEUdE described a Crotalus horridus var. unicolor from Aruba, which was afterwards regarded as C. terrificus, so that this species is found, though rarely, in both islands.

\section{AMPHIBIA.}

\section{CYSTIGNATHIDAE.}

Paludicola brachyops (Cope).

G. A. Boulenger, Cat. Batr. Sal. 1882, p. 232.

Hato, 28.4.1920, 1 spec., v. d. H. leg.

Known from Aruba only and said to have been imported from there into Curaçao with sand from the oilrefinery. It is the only species of Amphibians in the island. 